\title{
Comparative Analysis Of Land Space And Structural Facilities In Relation To Academic Output
}

\author{
Ijagbemi Christopher Oluwatade \\ M. TECH., MBA, FNIVS. \\ Department of Estate Management and Valuation. \\ Federal Polytechnic, Ado-Ekiti, Ekiti State
}

\begin{abstract}
The goal for attainment of sustainable infrastructure for cities and communities of the world was set to be attained latest by year 2030. Goal 11 of the Sustainable Development Goals (SDGs) specifically is about making cities and human settlements inclusive, safe, resilient and sustainable. This paper in consideration of this laudable goal considers vertical developments incorporating mixed use as an option to lateral development in educational institutions communities in Nigeria. Data were collected from selected educational institutions in Nigeria and were compared with similarly selected educational institutions outside Nigeria using internationally accepted ranking criteria as basis to see if possessing excessive land mass as observed in Nigerian Universities will lead to better academic performance and better world ranking as witnessed in foreign Universities. The result shows that total land mass available to educational institutions outside Nigeria is minimal, more productively used and effectively maintained in a sustainable manner than land available to higher institutions in Nigeria where land is awkwardly used and wasted. Higher Institutions should center more on research and academic excellence rather than possessing massive lands that are not effectively maintained. This work therefore recommends that Authorities in Nigeria should reduce land mass requirement for establishment of higher institutions and mandate investors to develop vertically by applying the mixed use concept.
\end{abstract}

KEYWORDS: SDGs, Vertical Development, Mixed Usage, Educational Institutions.

\section{Sustainable Development Goals (SDGs)}

Sustainable development is a development that meets the needs of the present generation without compromising the ability of the future generations to meet their own needs (World Commission on Environment and Development, 1987). Since the later part of the twentieth century, the negative impact of development in the environment with its damaging consequences has continued to bring fear into the minds of Environmentalists. Earlier studies tried to lay a foundation calling for sustainable development of land resources. Malthus (1798) attempted to address the issue of the Earth Carrying Capacity through his theory of exponential population and arithmetic food supply growth. Bartors(1995) addressed the issue of gradual change in temperature that could lead to ultimate death. Schumachar (1982) addressed the economic ideas that had sadly been forgotten such as the need for economic use of land resources and Holmberd (1991) wrote a masterpiece on the need for the present to defend the future. The Land Use Act (1978) in Nigeria was promulgated mainly to address the issue of Land Use and sustainability by putting the length and breadth of all the Lands in a State under one Caretaker - The Governor of the State. This is believed would lead to judicial distribution since ownership can be regulated to mean one man one plot. 
Due to all the natural calamities faced by the world and for the fact of the relationship between man and his environment where man must derive sustenance from the land he occupies, pitiably, man has been making attacks on his own environment by plundering it thereby threatening his own survival; Ijagbemi (2010). The enormous problem posed by human activities therefore has called for more sustainable management of resources Adegoke (2005).

Sustainable development concept therefore addresses issues of environmental friendliness in all ramifications of human development. The goals as spelt out at the UN Stockholm Conference on human environment in 1972, the Earth Summit in Reo De Janeiro, Brazil in June 1992 and the culminating declaration at the general assembly are all blue prints to achieve a better and more sustainable future for all; these are global goals to protect the planet earth and make it a better place for the present and generations yet unborn to live in.

\section{Vertical Development}

Property Development is faced with lots of risks right from inception to completion. In the sense of this work however, flexibility in use is being proposed as an option to counter some of these risks. Flexibility in use allows the Developer/Investor to mitigate some of the risks faced. Development takes place on land and for proper maintenance and effective use, vertical development then is seen as an option over lateral development for higher institutions.

Vertical Development in the settings of higher institution community is any development that rises above 4 floors. It is necessary to say that developments here can rise as high as available technology permits. Scientists and developers even as far back as early ages came into the understanding of the advantages of vertical development in the case of the Tower of Babel in the Bible. Since this time, such high rises have been employed, not for environmental beauty purposes only but more to make use of space and conserve land available.

Higher Institutions in countries all over the world have also keyed in into this phenomenon. The case in Nigeria Institutions should not be different then because of the advantages of economy in the use of land, this being a major reason for this option which makes it very attractive and the reason of sustainability, Pearson (2008). This advantage is being exploited maximally by the Government of China demonstrating this in all recent Government planned cities which favours High Density Developments. Nigerian Government on the other hand seems not to realize that though land is a free gift of nature it is not created by man hence its supply is fixed. Vertical Development is for the sustainability of this resource knowing full well that the built environment constitute one of the major consumption units of land. The Institutions requires a lot of land mass for physical development and other uses.

Vertical Development using the concept of mix-use is a feasible alternative therefore to the present lateral and sprawling concept. Dalal\& Bass (2012) opined that sustainable vertical development is perceived as a mixed use development (MUD) and is in the form of clusters of interconnected high rise buildings that facilitate quality environment to its inhabitants and visitors. Vertical cities (Vertival developments) is seen as a vision of a complete eco-system in the sky - a place you will never have to leave if you don't want to; Schiller, (2014).

\section{Mixed Use Development}

This is a type of development in urban centres that blends more than one use such as residential, commercial, cultural, institutional or entertainment. These functions are physically and functionally integrated thereby providing pedestrian connections. This kind of development can take the form of a simple building, a city block, or entire neighborhood's construction. This term may also be used more specifically to refer to a Mixed - Use Real Estate 
Development Project - a building, complex of buildings or district of a town or city that is developed for mixed - use by a private developer (quasi) Governmental agency, or a combination thereof. Modern settlements all over the world are now adopting mixed use pattern. Nigerian Institutions should subscribe to this idea rather than continue to allow their environment to be defaced with a large expanse of land rarely covered due to high level of availability. Instead of mapping out the area of land for the tangible development that will lead to aesthetically and sustainable development through the idea of vertical development that inculcate a lot of uses, land that ought to be conserved for the coming generations are wasted. Management or Government believes in scattered settlements which in turn cause the gross lack of proper management of the land and other landed properties, deforestation which leads to degradation. However, with industrialization as well as modern technology, the use of and the exploration of vertical space and its development should replace lateral development.

\section{Benefits Of Mixed - Use Development}

Better space allocation, guaranteed variety and density.

Reduction in distance covered by the Institutions community

More compact development, land - use synergy

Stronger neighbourhood character, sense of place

Reduced transportation cost as a result of walkable, bike - able neighbourhoods enjoying increased accessibility via transit points.

Properties can boast of luxurious shared facilities

Ease of facility maintenance

Reduction in cost of security as sections can be monitored by powerful CCTVs

Roads, Drainages, Electricity, Water Spraying points and other facilities can be provided with ease

\section{Types Of Contemporary Mixed - Use Zoning In Education Institution}

Mainstream classrooms mixed with offices on different floors within a single block.

General convenience block

Retail and service uses to service the offices

Centralised Parking with adequate security watch ( CCTV and human)

\section{Higher Educational Institutions}

These are institutions where people of different ages learn. Higher Institutions in the context of this study are the Universities and the Polytechnics. They provide a large variety of learning environments and learning spaces thereby forming unique communities.

\section{METHODOLOGY}

Data used in this write-up were sourced directly from the internet as they are ready available. Information on Ranking Criteria from Times Higher Education (THE), from Academic Ranking of World Universities (ARWU) and from Quacquarelli Symonds (QS) World University Ranking was obtained at the sites of these bodies. Information on current Ranking of Nigeria Universities was also obtained through the same means.

Due to the volume of information available at these sites, only the top 20 Universities were picked as these were considered enough for the analysis. Information on land mass by each institution was obtained from their sites. The ranking done by these bodies were then adopted for easy comparison. 


\section{DISCUSSION}

As at today, Nigeria has about 160 Universities made up of 50 Federal Universities, 45 State Universities and 65 Private Universities approved by the Nigeria University Commission (NUC 2019). The minimum land requirement to set up a University is 250acres (100hectres). Other requirements are proximity to source of water supply - probably building a dam, private accommodation to complement available hostel, setting of Agricultural farms etc. All these will take extra hectres of land.

In the context of this work, land is viewed from the physical angle (terra firma) which makes its supply to be inelastic. As a result of this peculiarity which differentiates land from other resources, the total area for mans use cannot be appreciably increased. Its usage, sharing and allocation methods for present uses must be in recognition of generations yet unborn that must equally have land available for their use. Allocation to higher institutions now must be economical and sustainable.

\section{Criteria For Ranking}

This is based on some general indicators which serve as basis for ranking. Generally, the following are considered:

- Alumni of the Institution winning Nobel prizes and field medals

- Staff of an Institution winning Nobel Prize and field medals.

- Highly cited researchers in 21 broad Subject categories

- Papers published in Nature and Science (publication output)

- Papers indexed in Science citation index (citation impact)

- Per capital academic performance of an Institution

Table 1: Times Higher Education (THE) Ranking

\begin{tabular}{|l|c|}
\hline CRITERIA & WEIGHT \\
\hline Teaching - the learning environment & $30 \%$ \\
\hline Research - volume, income and reputation & $30 \%$ \\
\hline Citations - research influence & $30 \%$ \\
\hline Industry Income - innovation & $2.5 \%$ \\
\hline International Outlook-staffs, students and research & $7.5 \%$ \\
\hline TOTAL & $100 \%$ \\
\hline
\end{tabular}

Source: Field Research 2019 
Table 2: Top 20 Universities Ranking Under (THE)

\begin{tabular}{|c|l|c|c|c|}
\hline S/N & \multicolumn{1}{|c|}{ NAME } & COUNTRY & RANK & $\begin{array}{c}\text { LAND } \\
\text { MASS(ACRES) }\end{array}$ \\
\hline 1 & University of Oxford & UK & 1 & 12.5 \\
\hline 2 & University of Cambridge & UK & 2 & 288 \\
\hline 3 & Stanford University & US & 3 & 8,180 \\
\hline 4 & Massach. Institute of Technology & US & 4 & 166 \\
\hline 5 & California Institute of Technology & US & 5 & 124 \\
\hline 6 & Harvard University & US & 6 & 210 \\
\hline 7 & Princeton University & US & 7 & 500 \\
\hline 8 & Yale University & US & 8 & 1,015 \\
\hline 9 & Imperial College London & UK & 9 & \\
\hline 10 & University of Chicago & US & 10 & 217 \\
\hline 11 & ETH Zurich & SWITZRLAND & 11 & \\
\hline 12 & John Hopkins University & US & 12 & \\
\hline 13 & University of Pennsylvania & UK & 13 & 694 \\
\hline 14 & UCL & US & 15 & 6,679 \\
\hline 15 & University of California, Berkeley & US & 16 & 299 \\
\hline 16 & Columbia University & US & 17 & 419 \\
\hline 17 & University of California, Los Angeles & US & 18 & \\
\hline 18 & Duke University & US & 19 & 4,800 \\
\hline 19 & Cornell University & US & 20 & \\
\hline 20 & University of Michigan Amador & & \\
\hline
\end{tabular}

\section{Source: Field Research 2019}

Table 3: Academic Ranking Of World University (ARWU) Ranking

\begin{tabular}{|l|c|}
\hline CRITERIA & WEIGHT \\
\hline Quality of Education & $10 \%$ \\
\hline Quality of Faculty (staff ) & $20 \%$ \\
\hline Quality of Faculty (subject category) & $20 \%$ \\
\hline Research Output (publication) & $20 \%$ \\
\hline Research Output (social science) & $20 \%$ \\
\hline Per capital Performance & $10 \%$ \\
\hline TOTAL & $100 \%$ \\
\hline
\end{tabular}

Source: Field Research 2019 
Table 4: Top 20 Universities Ranking Under ARWU

\begin{tabular}{|c|l|c|c|c|}
\hline S/N & \multicolumn{1}{|c|}{ NAME } & COUNTRY & RANK & $\begin{array}{c}\text { LAND } \\
\text { MASS(ACRES) }\end{array}$ \\
\hline 1 & Harvard University & US & 1 & 210 \\
\hline 2 & Stanford University & US & 2 & 8,180 \\
\hline 3 & University of Cambridge & UK & 3 & 710 \\
\hline 4 & Massachusetts Institute of Tech. & US & 4 & 166 \\
\hline 5 & University of California, Berkley & US & 5 & 6,679 \\
\hline 6 & Princeton University & US & 6 & 500 \\
\hline 7 & University of Oxford & US & 7 & 12.5 \\
\hline 8 & Columbia University & US & 8 & 299 \\
\hline 9 & California Institute of Technology & US & 9 & 124 \\
\hline 10 & University of Chicago & US & 10 & 217 \\
\hline 11 & Univ. of California, Los Angeles & US & 11 & 419 \\
\hline 12 & Yale University & US & 12 & 1,015 \\
\hline 13 & Connell University & US & 13 & 4,800 \\
\hline 14 & University of Washington & US & 14 & 703 \\
\hline 15 & University of California, San Diego & US & 15 & 2,141 \\
\hline 16 & University of Pennsylvania & US & 16 & 694 \\
\hline 17 & University College, London & UK & 17 & 299 \\
\hline 18 & John Hopkins University & US & 18 & \\
\hline 19 & Swiss Fed. Inst. of Tech. Zurich & SWITZERLAND & 19 & \\
\hline 20 & Washington University, St. Louis & US & 20 & 2,313 \\
\hline
\end{tabular}

Source: Field Research 2019

Table 5: Quacquarelli Symonds (QS) Ranking

\begin{tabular}{|l|c|}
\hline CRITERIA & WEIGHT \\
\hline Academic reputation from Global survey & $40 \%$ \\
\hline Employer reputation from global survey & $10 \%$ \\
\hline Citation per faculty form Scopus & $20 \%$ \\
\hline Faculty Student Ratio & $20 \%$ \\
\hline Proportion of International students & $5 \%$ \\
\hline Proportion of International faculty & $5 \%$ \\
\hline TOTAL & $100 \%$ \\
\hline
\end{tabular}

Source: Field Research 2019 
Table 6: Top 20 Universities Ranking Under QS

\begin{tabular}{|c|l|c|c|c|}
\hline S/N & \multicolumn{1}{|c|}{ NAME } & COUNTRY & RANK & $\begin{array}{c}\text { LAND } \\
\text { MASS(ACRES) }\end{array}$ \\
\hline 1 & $\begin{array}{l}\text { Massachusetts Institute of } \\
\text { Technology (MIT }\end{array}$ & US & 1 & 166 \\
\hline 2 & Stanford University & US & 2 & 8,180 \\
\hline 3 & Harvard University & US & 3 & 210 \\
\hline 4 & University of Oxford & US & 4 & 12.5 \\
\hline 5 & California Institute of Technology & US & 5 & 124 \\
\hline 6 & ETH Zurich-Swiss Fed Inst. of Tech & US & 6 & 710 \\
\hline 7 & University of Cambridge & UK & 7 & \\
\hline 8 & UCL (University College London) & UK & 8 & 299 \\
\hline 9 & Imperial College London & UK & 9 & \\
\hline 10 & University of Chicago & US & 10 & 217 \\
\hline 11 & National University of Singapore & SINGAPORE & 11 & \\
\hline 12 & Nanyang Technological University & SINGAPORE & 12 & 594 \\
\hline 13 & Princeton University & US & 13 & 500 \\
\hline 14 & Connell University & US & 14 & \\
\hline 15 & University of Pennsylvania & US & 15 & 694 \\
\hline 16 & Tsinghua University & CHINA & 16 & \\
\hline 17 & Yale University & US & 17 & 1,015 \\
\hline 18 & Columbia University & US & 18 & 299 \\
\hline 19 & EPFL Ecole Poly. Fed. de Lausanne & SWITZERLAND & 19 & 299 \\
\hline 20 & EPFL Ecole Poly. Fed. de Lausanne & UK & 20 & \\
\hline
\end{tabular}

\section{Source: Field Research 2019}

Table 1, 3 \& 5 above shows the criteria under which Universities are ranked. Weights are attached to show relative importance of each criterion.

Table 2, 4 \& 6 shows the top 20 World Universities rankings along with the landmass of each university (urban setting). Out of about 30 universities rated, only about 4 has landmass marginally above 1000 acres. This represents about 13.3\%.

\section{Framework For Rankings In Nigeria}

Nigerian Universities (along with other higher institutions) have specific bodies charged to rate them. These bodies are known as Regulators and they are as follows:

National Universities Commission (NUC) - Universities

National Board of Technical Education (NBTE) - Polytechniques \& Monotechnics

National Commission for Colleges of Education (NCCE) - Colleges of Education

\section{Criteria For Ranking Nigerian Universities (UNIRANK)}

- Being chartered, licensed/accredited by appropriate Nigeria higher education-related organisation.

- Offering at least 4-year undergraduate degree or postgraduate degrees

- Delivering courses predominantly in a traditional face to face, non distance education 
Table 7: Top 20 Universities Ranking Under NUC (UNIRANK)

\begin{tabular}{|c|l|c|c|c|}
\hline S/N & \multicolumn{1}{|c|}{ NAME } & CITY & RANK & $\begin{array}{c}\text { LAND } \\
\text { MASS(ACRES) }\end{array}$ \\
\hline 1 & University of Lagos & LAGOS & 1 & 1,100 \\
\hline 2 & University of Ilorin & ILORIN & 2 & 37,500 \\
\hline 3 & Ahmadu Bello University & ZARIA & 3 & 17,500 \\
\hline 4 & Obafemi Awolowo University & IFE & 4 & 12,500 \\
\hline 5 & University of Nigeria & ENUGU & 5 & 2,500 \\
\hline 6 & University of Ibadan & IBADAN & 6 & 6,375 \\
\hline 7 & Covenant University & OTA & 7 & 560 \\
\hline 8 & Fed. University of Tech. Minna & MINNA & 8 & 26,625 \\
\hline 9 & Landmark University & OMU-ARAN & 9 & 1,400 \\
\hline 10 & River State University of Science \& & PORTHARCOUT & 10 & 11,655 \\
& Tech & & & \\
\hline 11 & Fed. University of Technology & AKURE & 11 & 21,104 \\
\hline 12 & University of Benin & BENIN & 12 & 16,540 \\
\hline 13 & Federal University & OYE & 13 & 5,680 \\
\hline 14 & Adekunle Ajasin University & AKUNGBA & 14 & 11,040 \\
\hline 15 & Babcock University & ILISHAN, REMO & 15 & 925 \\
\hline 16 & University of Jos & JOS & 16 & 16,054 \\
\hline 17 & Ladoke Akintola Univ. of Tech & Ogbomosho & 17 & 8,550 \\
\hline 18 & Lagos State University & OJO & 18 & 1,600 \\
\hline 19 & American University of Nigeria & YOLA & 19 & 24,000 \\
\hline 20 & University of PortHarcout & PORTHARCOUT & 20 & 12,225 \\
\hline & & & \\
\hline
\end{tabular}

Source: Field Research 2019

Table 7 above shows the top 20 Universities in Nigeria by NUC ranking alongside their landmasses. Only one has a landmass that is significantly below 1,000acres. This represents just $5 \%$ of the whole. 
Table 8: World Ranking For Nigerian Universities

\begin{tabular}{|c|l|c|c|c|c|c|}
\hline S/N & \multicolumn{1}{|c|}{ NAME } & CITY & $\begin{array}{c}\text { LAND } \\
\text { MASS }\end{array}$ & $\begin{array}{c}\text { WORLD } \\
\text { SCORE }\end{array}$ & $\begin{array}{c}\text { NU } \\
\text { RANKING }\end{array}$ & $\begin{array}{c}\text { WORLD } \\
\text { RANKING }\end{array}$ \\
\hline 1 & University of Ibadan & IBADAN & 6,375 & 1145 & 6 & 1 \\
\hline 2 & University of Nigeria & ENUGU & 2,500 & 2125 & 5 & 2 \\
\hline 3 & OAU & IFE & 12,500 & 2244 & 4 & 3 \\
\hline 4 & Covenant University & OTA & 560 & 2291 & 7 & 4 \\
\hline 5 & Ahmadu Bello University & ZARIA & 17,500 & 2341 & 3 & 5 \\
\hline 6 & University of Lagos & LAGOS & 1,100 & 2583 & 1 & 6 \\
\hline 7 & Fed. University of Tech. Minna & 26,625 & 2784 & 8 & 7 \\
\hline 8 & University of Ilorin & ILORIN & 37,500 & 2786 & 2 & 8 \\
\hline 9 & University of PortHarcout & PORTHARCOUT & 12,225 & 2999 & 20 & 9 \\
\hline 10 & Federal University of Technology & AKURE & 21,104 & 3117 & 11 & 10 \\
\hline 11 & Adekunle Ajasin & AKUNGBA & 11,040 & 3479 & 14 & 11 \\
\hline 12 & Federal University of Technology & OWERRI & 10,120 & 3703 & 36 & 12 \\
\hline 13 & University of Benin & BENIN & 10,000 & 3721 & 12 & 13 \\
\hline 14 & Federal University of Agric & ABEOKUTA & 25,000 & 3737 & 21 & 14 \\
\hline 15 & Lagos State University & OJO & 1,600 & 3768 & 18 & 15 \\
\hline 16 & University of Uyo & UYO & 14,604 & 3805 & 25 & 16 \\
\hline 17 & University of Jos & JOS & 16,054 & 3812 & 16 & 17 \\
\hline 18 & Ladoge Akintola University of M & OGBOMOSHO & 8,550 & 3823 & 17 & 18 \\
\hline 19 & Bayero University & KANO & 16,420 & 3829 & 24 & 19 \\
\hline 20 & University of Calabar & CALABAR & 13,508 & 3928 & 56 & 20 \\
\hline
\end{tabular}

\section{Source: Field Research 2019}

This table observes the landmass of the top 20 Universities in Nigeria along with their world score. University of Ibadan is the most highly ranked University in Nigeria with a world score of 1145 score and urban landmass of 6375. University of Ilorin that has a world score of 2786 has a landmass of 37500.

\section{Table 9: Aggregate World Ranking}

This ranking is based on the ranking of the 3 International bodies above. A point of 20 is awarded to the top most in each ranking while 1 is awarded to the least. The points scored on the 3 is added and then used to prepare a table which forms the aggregate world ranking using THE ranking table. 


\begin{tabular}{|c|l|c|c|c|}
\hline S/N & \multicolumn{1}{|c|}{ NAME } & $\begin{array}{c}\text { AGGREGATE } \\
\text { POINT } \\
\text { (A+B+C) }\end{array}$ & RANK & LAND MASS(ACRES) \\
\hline 1 & Stanford University & 56 & 1 & 8,180 \\
\hline 2 & Massach. Institute of Technology & 54 & 2 & 166 \\
\hline 3 & Harvard University & 53 & 3 & 210 \\
\hline 4 & University of Cambridge & 52 & 4 & 288 \\
\hline 5 & University of Oxford & 51 & 5 & 12.5 \\
\hline 6 & California Institute of Technology & 44 & 6 & 124 \\
\hline 7 & ETH Zurich & 38 & 7 & N.A \\
\hline 8 & Princeton University & 37 & 8 & 500 \\
\hline 9 & Imperial College London & 36 & 9 & N.A \\
\hline 10 & University of Chicago & 33 & 10 & 217 \\
\hline 11 & Columbia University & 31 & 11 & 299 \\
\hline 12 & University of California, Berkeley & 30 & 12 & 6,679 \\
\hline 13 & Yale University & 26 & 13 & 1,015 \\
\hline 14 & University College London & 24 & 14 & N.A \\
\hline 15 & Univ. of California, Los Angeles & 22 & 15 & 419 \\
\hline 16 & University of Pennsylvania & 19 & 16 & 694 \\
\hline 17 & Cornell University & 17 & 17 & 4,800 \\
\hline 18 & John Hopkins University & 16 & 18 & N.A \\
\hline 19 & Duke University & 3 & 19 & N.A \\
\hline 20 & University of Michigan Amador & 20 & N.A \\
\hline
\end{tabular}

\section{Source: Field Research 2019}

The table shows the world rankings for the top Universities of the world. No Nigerian University made the list. Despite many of these Universities having landmass of less than 1000acres, they still made the top 20 best Universities of the world. 
Table 10: Top 20 Universities Ranking By Land

\begin{tabular}{|c|c|c|c|c|}
\hline RANK & WORLD UNIVERSITIES & LAND (ACRES) & NIG. UNIVERSITIES & LAND(ACRES) \\
\hline 1 & Stanford University & 8,180 & University of Ibadan & 6,375 \\
\hline 2 & Massach. Institute of Tech. & 166 & University of Nigeria & 2,500 \\
\hline 3 & Harvard University & 210 & Obafemi Awolowo University & 12,500 \\
\hline 4 & University of Cambridge & 288 & Covenant University & 560 \\
\hline 5 & University of Oxford & 12.5 & Ahmadu Bello University & 17,500 \\
\hline 6 & California Institute of Tech. & 124 & University of Lagos & 1,100 \\
\hline 7 & ETH Zurich & N.A & Fed. University of Tech. Minna & 26,625 \\
\hline 8 & Princeton University & 500 & University of Ilorin & 37,500 \\
\hline 9 & Imperial College London & N.A & University of PortHarcout & 12,225 \\
\hline 10 & University of Chicago & 217 & $\begin{array}{l}\text { Federal University of Tech. } \\
\text { Akure }\end{array}$ & 21,104 \\
\hline 11 & Columbia University & 299 & Adekunle Ajasin & 11,040 \\
\hline 12 & Univ. of California, Berkeley & 6,679 & $\begin{array}{l}\text { Federal University of } \\
\text { Technology }\end{array}$ & 10,120 \\
\hline 13 & Yale University & 1,015 & University of Benin & 10,000 \\
\hline 14 & University College London & N.A & Federal University of Agric & 25,000 \\
\hline 15 & $\begin{array}{l}\text { Univ. of California, Los } \\
\text { Angeles }\end{array}$ & 419 & Lagos State University & 1,600 \\
\hline 16 & University of Pennsylvania & 694 & University of Uyo & 14,604 \\
\hline 17 & Cornell University & 4,800 & University of Jos & 16,054 \\
\hline 18 & John Hopkins University & N.A & $\begin{array}{l}\text { Ladoke Akintola University of } \\
\text { Tech. }\end{array}$ & 8,550 \\
\hline 19 & Duke University & 8,691 & Bayero University & 16,420 \\
\hline 20 & $\begin{array}{l}\text { University of Michigan } \\
\text { Amador }\end{array}$ & 3,177 & University of Calabar & 13,508 \\
\hline
\end{tabular}

\section{Source: Field Research 2019}

Though the landmass of some of the top 20 Universities are not available for comparison, generally it is observed that the landmass of most of the top 20 Universities are less than 2000 acres which is believed to be sufficient. On the other hand, the landmass of most Nigerian Universities that are poorly rated are above 6000acres which is assumed should be the upper limit else not sustainable. 
Table 11: Ranking By Academic Excellence

\begin{tabular}{|c|c|c|c|c|}
\hline $\mathrm{S} / \mathrm{N}$ & WORLD UNIVERSITIES & WORLD RANK & NIG. UNIVERSITIES & WORLD RANK \\
\hline 1 & Stanford University & 1 & University of Ibadan & 1145 \\
\hline 2 & Massach. Institute of Tech. & 2 & University of Nigeria & 2125 \\
\hline 3 & Harvard University & 3 & Obafemi Awolowo University & 2244 \\
\hline 4 & University of Cambridge & 4 & Covenant University & 2291 \\
\hline 5 & University of Oxford & 5 & Ahmadu Bello University & 2341 \\
\hline 6 & California Institute of Tech. & 6 & University of Lagos & 2583 \\
\hline 7 & ETH Zurich & 7 & Fed. University of Tech. Minna & 2784 \\
\hline 8 & Princeton University & 8 & University of Ilorin & 2786 \\
\hline 9 & Imperial College London & 9 & University of PortHarcout & 2999 \\
\hline 10 & University of Chicago & 10 & $\begin{array}{l}\text { Federal University of Tech. } \\
\text { Akure }\end{array}$ & 3117 \\
\hline 11 & Columbia University & 11 & Adekunle Ajasin, Akungba & 3479 \\
\hline 12 & Univ. of California, Berkeley & 12 & $\begin{array}{l}\text { Federal University of } \\
\text { Technology }\end{array}$ & 3703 \\
\hline 13 & Yale University & 13 & University of Benin & 3721 \\
\hline 14 & University College London & 14 & Federal Univ. of Agric, Abeokuta & 3737 \\
\hline 15 & Univ. of California, Los Angeles & 15 & Lagos State University, Ojo & 3768 \\
\hline 16 & University of Pennsylvania & 16 & University of Uyo & 3805 \\
\hline 17 & Cornell University & 17 & University of Jos & 3812 \\
\hline 18 & John Hopkins University & 18 & Ladoke Akintola Univ. of Tech. & 3823 \\
\hline 19 & Duke University & 19 & Bayero University, Kano & 3829 \\
\hline 20 & Univ. of Michigan Ann Arbor & 20 & University of Calabar, Calabar & 3928 \\
\hline
\end{tabular}

\section{Source: Field Research 2019}

The above shows the world ranking of the top 20 Universities in the world alongside the top 20 Nigerian Universities. The world scores shows the level of performance and academic excellence of Nigerian Universities.

\section{RESULT}

It was observed that most Nigerian Universities have allocated land above 6000acres which could not be managed properly hence left in the hands of land grabbers and speculators. A lot of encroachment occurs on these lands. This greatly hinders the process of sustainability of land use in Nigerian Higher Institution communities as empty land are allowed to waste away with no definite time of when development will reach various phases of the land.

However, land use in developed nations are judiciously used, well maintained and properly managed for the sake of sustainability. Oxford University with an intake of over 24,000 students occupies only 12.5 acres of land with 12 faculties. This shows the level of compatibility and sustainability involved in the use and management of land. This institution was established as far back as 1096 when sustainability was still in the dreams.

Higher institutions are rated based on stability of academic calendar, staff strength, student's intake, number of faculties and departments, quality of research output, quality of lectures and facilities but never on the land mass of such institutions particularly those left to waste. 
Oluwatade, I. C. (2019). Comparative Analysis Of Land Space And Structural Facilities In Relation To Academic Output. Advances in Social Sciences

Table 12: Selected Higher Institutions outside Nigeria

\begin{tabular}{|l|c|c|c|c|c|}
\hline \multicolumn{1}{|c|}{ INSTITUTION } & $\begin{array}{c}\text { YEAR } \\
\text { ESTABLISED }\end{array}$ & $\begin{array}{c}\text { LAND } \\
\text { AREA(ACRES) }\end{array}$ & $\begin{array}{c}\text { STUDENT } \\
\text { POPULATION }\end{array}$ & $\begin{array}{c}\text { STAFF } \\
\text { STRENGTH }\end{array}$ & FACULTIES \\
\hline Columbia Univ. N.Y & 1754 & 299 & 27,492 & 3,999 & 18 \\
\hline Univ.of Hong Kong & 1911 & 132 & 28,744 & 3901 & 10 \\
\hline Oxford University & 1096 & 12.5 & 24,650 & 13600 & 12 \\
\hline Korea University & 1905 & 202.9 & 28,431 & 5,225 & 17 \\
\hline Univ. of Campinas & 1966 & 860 & 35,676 & 10,322 & 11 \\
\hline
\end{tabular}

Source: Field Research 2019

\section{CONCLUSION AND RECOMMENDATION}

The Institutions from developed nations were able to make use of vertical development and employed the idea of mixed uses in their choice of physical development. This helped them to conserve their valuable land resources available to them for the use of unborn generations. The use of vertical development makes the institutions arena to be more compact thence, effectively maintained in a sustainable manner. They were able to manage their huge number of staffs and students, incorporating a number of aesthetic facilities within the mapped out area.

The achievement of sustainable communities and cities all over the world as desired in the SDGS is a feasible goal In Nigeria if Government can actually guide against illegal structures and other undue developments on the campuses that leads to wasteful land. Government should drastically reduce the minimum land required by the required bodies before such institutions can be set up. Developers and Investors in this sector should be encouraged to make use of vertical development rather than lateral development. The minimum floors for the academic blocks and offices should be stated in the approved document setting up the institution.

\section{References}

Bartons, L. (1995) : Knowledge Management and Business model Innovation Https://boons.google .com.ng Holmberg J (1991) : Depending the future: A guide to sustainable Development https://www.amazon.com Ijagbemi C.O. (2010) : Assessment of valuation methods used for oil spillage in Delta, Edo and Ondo States of Nigeria : M. Tech Project (unpublished).

Federal Republic of Nigeria (1978) Land use Act, 1978

Malthus, T.R. (1798) : An Essay on the principle of population www. Economics discussion. net

Pearson J.R \&Wiltels K.S. (2008): Real options in Action: vertical phasing in communication Real Estate Development. (A Master of Science Degree project in Real Estate Development, Massachusetts Institute of Technology, U.S.A.

Schumeder E.F. (1973) Small is beautiful: Economics as if people mattered https://www.amazon.com 